\title{
A RETÓRICA A ALEXANDRE E OS ORADORES ÁTICOS
}

\author{
PIERRE CHIRON* \\ Université de Paris XII - Val de Marne \\ (Créteil, França)
}

\begin{abstract}
RESUMO: O primeiro avatar da retórica não é passar do estado de preceitos ao estado de discursos? Infelizmente, aquele ou aquela que procura enriquecer a leitura dos oradores gregos antigos através de uma comparação com o código de prescrições elaborado pelos retores tropeça numa dificuldade: nossa documentação técnica se enriquece, com a Retórica de Aristóteles, no momento mesmo em que a prática oratória declina. Hesita-se, então, com razão, em estabelecer correlações entre as duas, ainda mais que se pode atribuir a Aristóteles uma verdadeira reforma da retórica: com ele, mesmo se uma boa parte do material técnico se mantém, os princípios, o método e a terminologia evoluem consideravelmente. Existe, todavia, um tratado que - sendo bastante próximo cronologicamente da Retórica de Aristóteles - fornece, sem dúvida, considerada a sua data (c. 340?) e sua orientação sofística, uma ampla visão sobre o ensinamento dos retores pré-aristotélicos: trata-se da Retórica a Alexandre, correntemente atribuída, desde Pier Vettori, a Anaxímenes de Lâmpsaco. Propomos, aqui, estabelecer as grandes linhas de um método destinado a explorar sistematicamente essa versão antiga do código retórico para a exegese dos oradores áticos, e apresentar algumas de suas aplicações.
\end{abstract}

PALAVRAS-CHAVE: retórica grega pré-aristotélica; oradores áticos; Retórica a Alexandre.

O ponto de partida da presente reflexão foi a elaboração da edição crítica, para a Collection des Universités de France, dita "Collection Budé", da Retórica a Alexandre (abreviadamente, Rh. Al.) do Ps.-Aristóteles, freqüentemente atribuída ao retor e historiador Anaxímenes de Lâmpsaco (c. 380 - c. 320).

Uma das constatações principais que fizemos no curso de nosso trabalho é que as relações que existem entre esse tratado e a prática dos oradores áticos são extrema- 
mente estreitas. Em sua grande edição comentada, L. Spengel já registrava, para quase cada preceito, um grande número de referências a esse corpus.

Uma segunda constatação é que o material comparativo obtido, em nossa opinião bastante precioso para a exegese dos oradores, é apenas muito raramente explorado pelos comentadores destes últimos. Não existem, segundo nosso conhecimento, senão dois artigos que utilizam a $R h$. Al. como fonte principal para esse tipo de investigação. Raras também são as edições de oradores que mencionam a Rh. Al., malgrado algumas notáveis exceções como a edição do Erótico de Demóstenes feita por Robert Clavaud.

Tal lacuna correlaciona-se a um fenômeno mais geral: os aspectos propriamente retóricos da eloqüência grega são freqüentemente negligenciados. Na maior parte do tempo, os editores e comentadores se contentam em assinalar um topos, ou em estabelecer o caráter canônico de um desenvolvimento, notando a semelhança, por exemplo, dum exórdio com outro exórdio, o que permite concluir sobre a existência de coleções de exórdios-modelos - dos quais a tradição, aliás, conservou-nos um exemplar com os Prólogos de Demóstenes. Tal método tem um caráter simplista e redutor e, o que é mais grave, freqüentemente deixa transparecer um dos mais antigos preconceitos de que a retórica sofreu: esta se reduziria ao lugar-comum, à retomada mecânica dos mesmos procedimentos. Esse preconceito transparece no caráter pontual desses comentários, mas sobretudo na pobreza do método crítico, pobreza induzida, provavelmente, pelo sentimento de que não há nada, aí, para descobrir. Procede-se, com demasiada freqüência, por redução dos fenômenos a um denominador comum (o que constitui uma primeira traição, ao menos se se fica por aí) e por aplicação implícita de critérios anacrônicos, de toda maneira não-adaptados, para desqualificar os aspectos retóricos. Esses critérios, como a originalidade, a espontaneidade, correspondem a valores que não têm senão uma reduzida pertinência na época clássica. Da mesma maneira, a preocupação com verdade factual, a prática de raciocínios indutivo-dedutivos, não devem servir como padrões. Tal preocupação, tais raciocínios não foram verdadeiramente teorizados senão no fim do período de produção dos oradores áticos, por Aristóteles, e não convêm muito à apreciação plena e inteira desses textos mais antigos, ancorados nos debates reais e voltados mais para o domínio da opinião que para o raciocínio rigoroso a partir de premissas prováveis. Se se trata de dizer que os oradores antigos têm pouca preocupação com a verdade e que eles se repetem uns aos outros, $o$ resultado é passavelmente trivial e desprovido de interesse. Se, por outro lado, se aprecia a qualidade desses textos por sua capacidade de se destacar do modelo retórico, é expor-se a ignorar um fato muito provável: a presença de um modelo retórico requintado e complexo explica a riqueza do corpus dos oradores áticos. Não é malgrado o 
código retórico que os oradores áticos produziram seus melhores textos, mas parcialmente graças a ele, num jogo complexo de coincidências e de desvios que devem ser estudados e interpretados com cuidado.

\section{A $R h . A l$. como fonte privilegiada}

Mas antes de propor alguns elementos de método para um tal estudo e alguns exemplos de sua aplicação, convém justificar a escolha da Rh. Al. como instrumento privilegiado desta pesquisa inter/hipertextual.

É verdadeiramente pertinente, em primeiro lugar, aproximar a Rh. Al. do corpus dos oradores? Seremos muito breve sobre esse ponto, que mereceria só para si uma explicação particular. Duas questões se colocam: Por que não se utilizou mais amplamente a Rh. Al. para a leitura dos oradores? A Rh. Al. coincide com os manuais que presidiram à formação dos oradores áticos? É evidente que se o código que nela se encontra foi elaborado a partir dos textos, o sentido e o valor das aproximações que se podem fazer entre os dois tipos de produção são inteiramente diferentes.

Para responder à primeira questão - por que a $R h$. Al. não foi usada mais amplamente como contribuição pela crítica - pode-se dar, ao menos no domínio francófone, uma primeira razão muito prosaica: para os não-helenistas, o texto é acessível apenas em inglês, em alemão e em espanhol. A primeira e última tradução francesa - de Jules Barthélémy Saint-Hilaire - data de 1870 e não se distingue por sua exatidão.

Há uma outra razão: as dúvidas que pesam sobre a atribuição do Tratado. $\mathrm{O}$ texto foi transmitido no seio do corpus aristotélico, mas evidentemente não é de Aristóteles. Hesita-se, pois, em contar com um texto de origens incertas. A hipótese de atribuição da obra a Anaxímenes de Lâmpsaco, isto é, a um sofista, não deve ter encorajado os críticos: o tratado caiu sob o impacto da suspeita que tradicionalmente pesa sobre a corrente sofística. Felizmente, trabalhos recentes mostram que essa corrente está em processo de reavaliação.

Enfim, o mal estado do texto, parcialmente retocado, como o provam as diferenças substanciais entre o PHib. 26 e a tradição medieval, faz da Rh. Al. uma obra difícil de estabelecer e de interpretar. Como se vê, as razões da relativa indiferença da crítica são mais conjunturais que essenciais.

Mas resta estabelecer a coincidência entre a $R h$. Al. e os manuais em uso no IVo século. Do ponto de vista cronológico, os elementos seguros determinam para o 
Tratado um "garfo" de datação compreendido entre 340 e 300. O terminus a quo é fornecido pela menção, no cap. 8, da expedição dos Coríntios a Siracusa (c. 344/343). A existência de um fragmento papirológico datado de c. 250 permite, levando em conta alguma demora requerida pela divulgação, pela utilização, pela rejeição e pelo reemprego do documento, fixar o terminus ante quem em 300.

Todo o afinamento da datação leva a colocar a questão das relações entre a $R h$. Al. e Aristóteles. Tais relações são complexas, pois o retor utiliza um modo de apresentação às vezes bastante abstrato que faz pensar muito no Estagirita, e os "pontos" teóricos entre a Rh. Al. e a Retórica não faltam. Mas tais semelhanças são superficiais e não dissimulam divergências muito profundas: o retor está ancorado na tradição sofística revista e corrigida por Isócrates. Seu projeto tem um caráter profissional, empírico, prático, como o testemunha - entre muitos outros indícios - o tratamento de formas oratórias muito particulares negligenciadas por Aristóteles, o discurso de embaixada e o discurso de exame. A hipótese de datação mais razoável nos parece ser a de Spengel e de Blaß: c. 340, isto é, depois da elaboração dos dois primeiros livros da Retórica (período acadêmico, c. 350) e antes da publicação da Retórica completa (entre 334 e 322).

Tal datação situa o Tratado no coração do período de produção de Demóstenes, e torna, pois, muito provável a coincidência entre o essencial de seu conteúdo e o dos manuais em uso na primeira metade do IVo século. Infelizmente, não se pode dizer muito mais sobre isso.

\section{Questões de método}

Mas qual método adotar para que uma confrontação entre o código retórico e a prática oratória seja fecunda?

Um caminho ao mesmo tempo rigoroso e produtivo foi aberto por Francisco Cortés Gabaudán. Este último se dedicou à localização de fórmulas correspondentes a "funções", fórmulas de introdução das provas e dos testemunhos, fórmulas de pedido, fórmulas de introdução da narração... O método é aperfeiçoado pela distinção de "núcleos formulares" e de elementos mais variáveis. Os resultados obtidos são muito interessantes: F. C. Gabaudán pôs em relevo recorrências, certamente, mas também diferentes tipos de variações, variações no interior da mesma obra, mas também variações de um autor para outro, o que lhe permitiu obter critérios de autenticidade, no seio do corpus demosthenicum, particularmente. Esses resultados puderam servir de suporte a 
interpretações mais ambiciosas, como no caso do pedido $(\alpha$ ”ı $\tau \eta \mu \alpha)$ : a ampliação das aproximações aos textos dramáticos permitiu ressaltar o caráter - e sem dúvida a origem - ritual, quase religioso, desse procedimento recorrente do exórdio.

Mas é possível, acreditamos, explorar ainda mais sistematicamente e de maneira mais completa o código retórico. Parece-nos que convém colocar em jogo ao mesmo tempo o máximo possível de critérios, atentando para:

1) a exposição de recorrências (discurso/discurso/código);

2) o exame da taxis (lugar do elemento codificado no discurso);

3) o registro exaustivo dos fatos: para isso, é preciso trabalhar sobre todo um discurso, com o qual se confrontará a integralidade do código, constituindo o número de coincidências a melhor confirmação, sem dúvida, da presença do modelo retórico.

A esses critérios, que se poderiam qualificar como elementares, deve-se acrescentar:

4) a ampliação da pesquisa aos tipos funcionais, independentes da formulação.

Tal ampliação é necessária, pois a codificação dos procedimentos toma freqüentemente a forma, na Rh. Al., da descrição de um método. A coincidência com o código se extrairá não somente de uma semelhança terminológica, mas de uma semelhança metodológica, cujo caráter retórico deverá ser corroborado por um desvio em relação às normas do raciocínio dialético. Pode-se objetar, aqui, que acrescentamos um intermediário inútil entre o código retórico e os textos. A resposta a essa objeção relaciona-se com as características da elaboração dos procedimentos na $\mathrm{Rh}$. Al. O que serve ao retor para individualizar uma pistis não é tanto o modo de raciocínio implicado mas o material utilizado. Ele define, primeiramente, um domínio de pesquisa (tópica), depois indica, na seqüência, o modo de extração da pistis. Segue, daí, que um mesmo modo de raciocínio se aplicará a várias pisteis, diferenciadas somente por seu material.

Demos um exemplo: o retor define o signo ( $\sigma \eta \mu \varepsilon i \hat{o} v)$ por seu substrato, a saber, uma relação habitual de sucessão ou de concomitância entre fatos (Rh. Al., cap. 12). Essa relação de concomitância ou de sucessão não se distingue de uma relação de causalidade. Pode-se construir, a partir daí, um raciocínio do tipo: há uma mancha de sangue; ora, uma mancha de sangue acompanha um crime; logo, houve crime. $\mathrm{O}$ raciocínio fundado sobre essa relação, é possível constatar, não é essencialmente dife- 
rente do raciocínio por associação-extensão que serve, por exemplo, para a argumentação pelo verossímil (દ่ıKós, cf. Rh. Al., cap. 7, 1428 a 25ss); por exemplo: habitualmente os jovens são violentos; ora, ele é jovem; ele se portou, então, de uma maneira violenta. A diferença entre signo e verossimilhança reside apenas em seu material, de um lado os fatos, de outro os prejulgamentos acumulados graças à experiência. Parecenos importante extrair o sofisma comum, isolar pisteis particulares que o utilizam, a fim de clarificar as coisas e de assegurar a exaustividade das aproximações entre o código e os textos oratórios.

Esses tipos funcionais que podem orientar a pesquisa, parece-nos, são quatro:

1) Modificação da perspectiva. Esse trabalho de ilusionista comporta, ele mesmo, quatro tipos principais de meios:

- o que se poderia chamar de "efeito de massa", que coincide com efeitos variados: desde a mentira por adição até aos numerosos meios da amplificação estilística (perífrases, antíteses, isocola, etc.);

- o efeito de contraste, pela justaposição de elementos escolhidos e pela valorização de sua desproporção;

- o efeito de "competição", pela confrontação - seguida de uma análise comparativa - do bem (ou do mal), de que se fala, com um bem ou um mal reconhecidos como tais;

- o despertar da imaginação, procedendo por aquilo que se poderia chamar de omissão "plena" (por "plena", entendemos plena de subentendido).

2) Omissão simples.

3) Defloração (o argumento tem mais força na primeira vez em que é apresentado).

4) Exploração das induções espontâneas (por radicalização, extensão, deformação). É todo o domínio do Ėikós sofístico: o melhor meio de ser crido consiste em dizer alguma coisa que é conforme com os prejulgamentos do público. Esse princípio encontra sua plena aplicação no ofício do sicofanta: se se censura alguém de jovem, forjar-se-á um ponto de acusação conforme com as idéias tomadas sobre o comportamento dos jovens. Mas todo o mundo sabe que o que é provável não é certo, que o que é verossímil não é forçosamente verdadeiro. $\mathrm{O}$ primeiro sofisma consiste em passar da probabilidade à certeza. É o que se chama radicalização. Em vez de dizer: é provável que ele roubou, dir-se-á que ele roubou. Por outro lado, pode-se operar um certo número de insinuações (extensão): por exemplo, se alguém mentiu 
para mim várias vezes, essa experiência renovada permite a indução seguinte: tal sujeito é um mentiroso, e permite dizer - se ele é, por exemplo, candidato a uma magistratura: não lhe dês confiança, pois ele mentirá. Sobre essa base, a extensão consiste em dizer: "aquele que mente é capaz de todas as vilanias". Compreende-se que essa estratégia argumentativa se presta também a todos os tipos de deformações, que não podemos examinar aqui.

Mas o limite dessa pesquisa de tipos funcionais é que ela isola o texto como "autotélico". Uma abordagem "pragmática" deverá vir como complemento, na medida do possível, a fim de prolongar a localização dos meios utilizados através de uma apreciação de sua pertinência. Donde um quinto tipo de pesquisa, mais propriamente exegética:

5) Passagem à exegese.

A interpretação das aproximações obtidas pode-se fazer, conforme nos parece, por meio de uma segunda tipologia destinada a identificar a relação com o código mantida pelo discurso estudado. A relação retórica é analisada, desde Aristóteles, como uma relação de três termos: o orador, o público, o processo. Parece-nos, em primeiro lugar, que, nos processos judiciários pelo menos, intervém o adversário, como quarto termo, mas sobretudo que o código retórico deve intervir como quinto parâmetro a título de mediato entre todos os outros termos.

Por quê? O código é indispensável ao orador se ele quer conseguir a persuasão; por outro lado, é esse código que serve para dar forma aos fatos, levando-se em conta a influência que se tenta exercer sobre o público. De sua parte, o público e eventualmente o adversário, que conhecem provavelmente o código (estamos falando do IVo século a. C., em Atenas), percebem uma realidade informada pelo código retórico, e a consciência que eles têm ou não da existência do mediato é um fator que influi enormemente sobre a persuasão. Não queremos dizer que todos os atenienses do IVo século conheciam a retórica. Os retores, isto é, os homens políticos, não eram muito numerosos (pouco mais de 20 em atividade no mesmo momento, segundo M. H. Hansen), mas a participação de um número muito grande de cidadãos na vida política (um ateniense em cada quatro era chefe do executivo um dia em sua vida) e na vida judiciária (a cada ano seis mil jurados [dicastas] estavam em atividade) devia criar, ao menos por embebição, uma certa competência entre o público. 
Nessas condições, a posse, o domínio do código é um dos principais objetivos da retórica. $\mathrm{O}$ orador eficaz é aquele que o utiliza sem que ninguém o detecte, o contraditor e o público eficazes são aqueles que detectam a presença dele e que são capazes, portanto, de lhe medir a pertinência e, se a ocasião se apresentar, os artifícios. Acrescentemos que, numa ótica agonística, o prestígio da competência, a admiração provocada por um domínio virtuoso da retórica pode ter sobredeterminado a percepção do código e complicado as coisas.

Mas que trabalho podemos fazer sobre essa rede de relações? Existem, a nosso ver, duas direções essenciais a explorar, que mantêm relações dialéticas entre si: de um lado, a natureza da relação entre o orador e o código retórico; do outro lado, a pertinência dessa relação em consideração à matéria tratada, às reações do auditório e à eventual resposta do contraditor. Essas duas pistas poderiam constituir a abscissa e a ordenada do quadro seguinte:

\section{relação orador / código pertinência da relação orador / código em face}

\begin{tabular}{|l|l|l|l|}
\hline & dos fatos & do adversário & do público \\
\hline aplicação & & & \\
\hline reviramento & & & \\
\hline negação & & & \\
\hline sobredeterminação & & & \\
\hline
\end{tabular}

Se quiséssemos preencher um tal quadro para cada discurso conservado, haveria necessidade de informações que não são sempre disponíveis. O nível exato da formação dos oradores, a realidade dos fatos (que freqüentemente são conhecidos apenas por uma única fonte), o conteúdo dos discursos dos adversários, o resultado dos processos ou das deliberações não são sempre acessíveis.

Para o presente artigo, limitar-nos-emos a alguns casos pontuais mas considerados significativos, seguindo a ordem indicada na primeira coluna.

\section{Alguns exemplos}

\subsection{Aplicação do código}

Comecemos pelo mais simples, a saber, a aplicação do código. Na tradição sofística, dizíamos, a retórica visa a uma modificação da perspectiva. 


\subsubsection{Modificação da perspectiva}

O principal meio é o efeito de massa, efeito cujo princípio é dado no cap. 3 da $R h$. Al., a propósito do elogio e da censura. O retor escreve:

O elogio é a amplificação ( $\alpha$ ǔ $\xi\rceil \imath \zeta)$ de opções, de ações e de discursos honrosos e a anexação (sc. ao objeto do elogio) de tais bens se eles

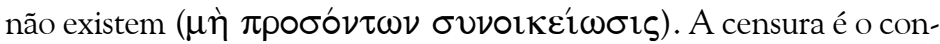
trário, o rebaixamento do que é honroso e a amplificação do que é vil (Rh. Al., 3, 1425 b 36-39).

Observou-se que o conselho de aumento vai até à mentira. Detalhe curioso, o editor da Rh. Al. na Bibliotheca Teubneriana desconfia desse membro de frase; ele escreve no aparato: "essas palavras não condizem com a construção habitual nas definições e a palavra $\sigma v v o ı \kappa \varepsilon i \omega \sigma ı$ cheira à grecidade tardia". Parece, sobretudo, que ele se assustou com a enormidade do preceito. No entanto, ele se reencontra tal qual em Isócrates no Busíris (4) e Sócrates lhe faz referência ironicamente no Menexeno; citemos esta última passagem:

De fato, Menexeno, poderia ser que, de muitas maneiras, morrer na guerra fosse uma coisa bela. Pois não contente com ganhar uma bela e luxuosa sepultura - mesmo se se morreu pobre - , obtém-se, além disso, um elogio - mesmo se não se vale nada, da boca de pessoas sábias e que não louvam ao acaso, não, mas com discursos preparados há muito tempo; eles o louvam tão bem, que, ao atribuir a cada um as qualidades

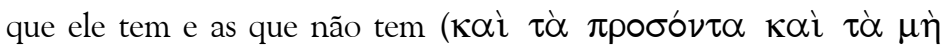
$\kappa \tau \lambda$.), com um cintilante adorno de palavras, enfeitiçam nossas almas $(234 \mathrm{c}-235$ a 1$)$.

Mas qual paralelo dar na prática oratória? Escolhemos voluntariamente uma passagem anódina do Contra Ctesifonte. Ésquines está no primeiro ponto de direito: Ctesifonte cometeu uma ilegalidade ao pedir uma coroa para um magistrado que não havia prestado suas contas. $\mathrm{O}$ orador diz:

Depois disso, cidadãos de Atenas, eles terão um segundo raciocínio

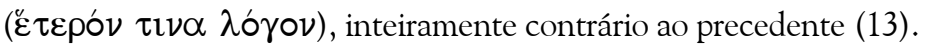


Não há nada, aí, que chame a atenção, salvo que, se se observa o que precede, procurase em vão o menor traço desse primeiro raciocínio. Ésquines, aliás, é extremamente atento ao rigor das transições e à clareza da estruturação de conjunto. Sob reserva de um problema textual - mas nem a edição Budé nem a recente edição Dilts dizem algo

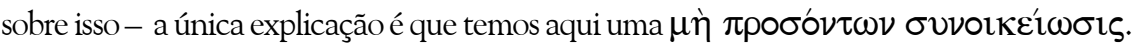
Ésquines quer, por meio desse artifício, aumentar a lista de raciocínios especiosos que ele atribui antecipadamente a seus adversários. Isso pode parecer surpreendente, até porque o Contra Ctesifonte não é um discurso epidítico stricto sensu e mistura as técnicas do judiciário às da censura. Mas o autor da Rh. Al. sublinha que os métodos do elogio e da censura são extensíveis a outros gêneros oratórios. Para quem ache o ardil demasiado evidente, é preciso considerar o fato de que a retórica é uma arte da oralidade: é possível que os ouvintes não tenham visto aí senão veemência. Na escrita, isso passa menos bem, e se os editores modernos não assinalam a dificuldade, o escoliasta mais atento - escreve: "ele não mencionou antes nenhum raciocínio dos adversários; como, então, ele pode dizer 'um segundo raciocínio'?"

A essa técnica da mentira por adição, que mereceria um estudo somente para ela, acrescentam-se as técnicas de aumento. Os exemplos disso são muito numerosos; ainda no Contra Ctesifonte, citemos a frase:

Empenho-me em demonstrar aos jurados que a causa da salvação da

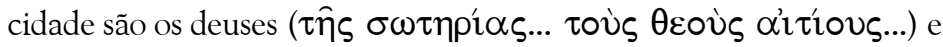
aqueles que a trataram em certas circunstâncias com humanidade e moderação (sc. Felipe e Alexandre), ao passo que a causa de absolutamente todas ( $\alpha \dot{\alpha} \alpha \nu \tau \omega \nu)$ as suas infelicidades é Demóstenes (57),

frase que se pode aproximar de Rh. Al. 3 (1426 b 7-8):

Em suma, se tu fazes ressaltar que aquilo de que tu falas é a causa de muitas coisas ( $\alpha^{\prime} \imath \tau \imath o v \pi 0 \lambda \lambda \hat{\omega} \nu$ ), quer seja de bens ou de males, tal coisa parecerá grande.

Esse aumento direto por exageração é o mais simples. Precisemos que ele funciona tanto no nível do conteúdo quanto no nível estilístico; os conselhos técnicos nesse domínio consistem em:

- multiplicar as divisões: meio hábil que consiste em estender a matéria sob a aparência de análise. Pode-se dar, como exemplo, a genealogia. Se se quer ser conciso, adotar-se-á a fórmula do tratamento global (ancestrais gloriosos); mas é possível es- 
tender infinitamente a matéria com o auxílio do tratamento analítico: ancestrais humanos / ancestrais divinos, ancestrais próximos / distantes. Depois, para cada ancestral, qualidades físicas / qualidades morais / proezas, etc. etc.;

- introduzir em toda a parte fórmulas de recapitulação e de transição;

- "utilizar sobre cada ponto muitas palavras" (Rh. Al., 22, 1434 b 5-6).

Nessas técnicas de amplificação, há uma das competências mais espetaculares dos sofistas, como testemunha Platão (Protágoras, 334 e):

Sócrates: Eu ouvi dizer, disse eu, que tu (sc. Protágoras) és capaz - dizem até que tu podes comunicar esse talento aos outros - de tratar as mesmas matérias, se tu queres, com uma abundância tal que a palavra nunca te falta, ou com uma brevidade tal que ninguém pode exprimirse com menos palavras. Se tu queres, pois, discutir comigo, adota a segunda maneira, a maneira concisa.

Assim se explicam as digressões, os redobramentos de sinônimos, as hendíadis, as perífrases, etc. tão freqüentes nos oradores. Esse estudo estilístico constitui um vasto campo, que não podemos mais do que aflorar aqui.

Depois desse trabalho sobre o volume, recorrente também é o trabalho sobre o contraste. A Rh. Al. é bastante explícita:

Em todos os casos, será possível amplificar assim: se tal coisa é julgada um grande bem, o seu contrário, se tu o dizes, aparecerá como um grande mal. De igual maneira, se ela é considerada como um grande mal, se tu dizes $<$ o seu $>$ contrário, esse aparecerá como um grande bem (1426 a 31-35).

Tomemos para exemplo o Contra Ctesifonte. Ésquines acaba de examinar a política de Demóstenes, cujo caráter nocivo ele tentou mostrar. Ele supõe, então, que se lhe faça a seguinte objeção: "sim, mas é um democrata" e prossegue:

Eu vou examinar convosco qual deve ser a natureza do democrata e do homem honesto, e em seguida oporei (' $\alpha \nu \tau \imath \theta \dot{\eta} \sigma \omega)$ a esse retrato o que é o oligarca e o mau cidadão (168).

Ésquines apresenta em seguida as cinco características do democrata: é um homem de nascença livre, de família honrosa, moderado e modesto na sua vida cotidi- 
ana, capaz de aconselhar seus concidadãos com bom senso e eloqüência, é um homem corajoso. Confronta, depois, com cada elemento desse retrato uma seleção tendenciosa de elementos tomados da biografia de Demóstenes: ele tem, da parte de sua mãe, sangue cita, seu avô Gilão foi condenado por traição, ele dilapidou seu patrimônio e vive agora dos frutos de sua corrupção, sua eloqüência contrasta com a perversidade de seus costumes, e enfim é um frouxo.

Ao lado desse trabalho bastante simples sobre o contraste ou a antítese, a $R h$. Al. descreve um outro modo de amplificação, menos conhecido, que se pode chamar "por competição":

O segundo (modo de amplificação) consiste em apresentar um bem - se tu louvas -, ou um mal - se tu censuras -, reconhecidos como grandes; em examinar, a seguir, aquilo de que tu falas; e depois em compará-los entre si, detalhando o que há de maior do teu lado e o que há de menor do outro: aquilo de que tu falas sairá daí amplificado $(3,1426$ a 23-27).

O procedimento é ilustrado pelo retrato comparado de Alcibíades e de Mídias (Contra Mídias, 143ss). Ponto por ponto, Demóstenes mostra que o grande criminoso - de notoriedade pública - que é Alcibíades não chega aos pés de Mídias:

Entregou-se ele a violências tão graves quanto aquelas de que hoje se provou ser este homem culpado?

- Ele bateu bem na cara de Táureas, que era corego.

- Admito, mas era um corego que tratava assim um outro corego, e ele não podia violar ainda a lei de agora.

- Ele fez meter na prisão o pintor Agatarco, segundo dizem.

- Sim, mas ele o surpreendeu em flagrante delito (com a mulher de Alcibíades).

- Ele mutilou as imagens de Hermes.

- Todos os atos sacrílegos merecem, a meu ver, a mesma indignação; mas a destruição total dos ornamentos sagrados (o que Mídias queria fazer) é outra coisa que uma mutilação, etc.

Essa técnica é sem dúvida muito antiga. Encontramo-la em Isócrates. No Sobre $a$ Troca (79ss), Isócrates parte assim da atividade do legislador, reconhecida como útil 
entre todas e dotada do prestígio de um Sólon ou de um Clístenes, e esforça-se por mostrar que sua obra de retor é ainda mais útil, porque mais nova, mais universal, etc. Em Lísias também se pode detectar um emprego dessa técnica, ainda que menos vistoso, no Em defesa de Mantiteu. Esse Mantiteu, jovem manifestamente brilhante por suas qualidades pessoais e sua origem social, foi tirado à sorte como buleuta. No curso do exame, alguém o acusa de ter sido cavaleiro durante o governo dos Trinta. Para a sua defesa, o jovem descreve seus atestados de serviço. Durante a campanha de Corinto (394) os atenienses experimentaram reveses. Mantiteu relata:

Enquanto os outros se metiam debaixo da terra, eu me ajeitava para estar na primeira linha. Justamente nossa tribo foi a que mais se pôs à prova, e foi ela que perdeu mais gente: eu deixei o campo de batalha depois do ilustre cidadão de Esteiria, que a todos censurou a frouxidão (15).

Os comentadores identificam aqui, por detrás da perífrase, Trasibulo, o herói da restauração democrática de 403. Alguns sugerem que a passagem contém uma "zanga" contra esse grande personagem. Não acreditamos muito nisso: o que seria mais desastrado, quando se é acusado de simpatias oligárquicas, do que criticar o primeiro da fila dos democratas? Preferimos ver aqui um emprego da amplificação por competição. "Ninguém põe em dúvida a coragem de Trasibulo, parece dizer Mantiteu. Pois bem, eu, numa circunstância, deixei o campo de batalha depois dele." O objetivo é glorificar Mantiteu, não denegrir Trasibulo.

O trabalho sobre a perspectiva pode também se fazer por meio de despertar e orientar a atividade da imaginação, particularmente com o auxílio do subentendido. A teoria está apenas nos seus inícios na $\mathrm{Rh}$. Al., que se contenta em mencionar, entre os procedimentos que dão refinamento ao discurso, a arte de truncar entimemas de uma de suas premissas. Citemos:

O falar refinado pode ser obtido a partir do torneio que consiste, por exemplo, em enunciar entimemas - completos, de resto - apenas pela metade, de sorte que os ouvintes compreendam por seus próprios meios a outra metade $(22,1434$ a $34-37)$.

A passagem é difícil, por razões textuais (o texto citado é em parte conjetural), e também porque a noção de entimema não é muito claramente definida no tratado. Mas a idéia se esclarece um pouco quando lemos as considerações de Aristóteles sobre 
o entimema como silogismo retórico, isto é, um silogismo de premissas prováveis, do qual uma das premissas é omitida. Um entimema completo, por exemplo, é: "Aquele que pode salvar, pode perder; ora, eu pude salvá-lo; eu poderia, portanto, perdê-lo". Sob a forma do entimema, dá-se a frase da Medéia de Ovídio citada por Quintiliano (VIII, 5, 6): servare potui, perdere an possim rogas (Pude salvá-lo, e tu perguntas se eu poderia perdê-lo).

A supressão de uma premissa é motivada, diz Aristóteles, pela necessidade de adaptação à fraqueza intelectual do público, refratário aos raciocínios longos. Mas ela é justificada também pelo prazer de compreender, de decifrar (Ret., 1410 b 10-27). O estilicista Demétrio atribui a Teofrasto um desenvolvimento mais geral sobre esse tema:

Não é preciso falar longamente de tudo em detalhes, mas deixar ao ouvinte certas coisas para compreender e para deduzir por si mesmo; com efeito, quando ele compreendeu o que você calou, ele não é mais apenas um ouvinte, ele se torna sua testemunha, e, daí por diante, está melhor disposto; ele se crê inteligente graças a você, que lhe deu a impressão de compreender. Explicar tudo como para um imbecil pode passar por uma marca de desprezo para com o ouvinte (Do Estilo, $222=$ Teofrasto, fr. VIIb Mayer $=696$ Fortenbaugh).

O procedimento não é falto de analogia com um outro procedimento, a paraleipsis, ou preterição, que consiste em dizer que não se diz alguma coisa, dizendo-a, no entanto (Rh. Al., 21, 1434 a 17ss; Demétrio, Do Estilo, § 263). A análise nos leva a destinar à preterição cinco funções:

- uma função enunciativa: dizemos o que temos de dizer;

- uma função amplificadora: damos a entender que temos muito mais coisas para dizer do que dizemos;

- uma função emotiva: jogando com o imaginário, estimulado pela obscuridade voluntária, aproveitamo-nos da tendência natural do destinatário à inquietação, e até ao medo, ou somente a uma interpretação negativa dos elementos dados, no modo do rumor;

- uma função argumentativa: a dedução é orientada pelos elementos fornecidos: o destinatário não decifra senão aquilo que o fazemos decifrar. Demétrio diz: fazemos do destinatário uma testemunha;

- uma função ética: o orador parece se abster, ou pelo menos se conter, o que lhe confere um éthos de moderação. 
Na prática, pode-se citar, entre muitos outros exemplos, o Contra Nicômaco (2) de Lísias:

Que o pai de Nicômaco foi escravo público, qual existência ele mesmo levou em sua juventude, com que idade ele foi introduzido em sua fratria,

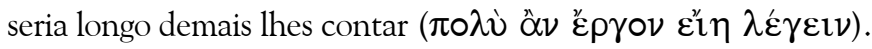

O caráter tópico do procedimento é provado pela recorrência freqüente, em vários auto-

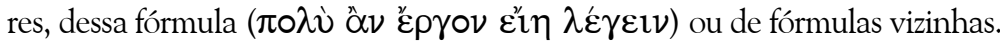

\subsubsection{Omissão}

Passemos ao segundo tipo de procedimento sofístico: outro tipo de mentira, a omissão. Mas se trata, desta vez, de uma omissão simples, e não de uma omissão fictícia, como no caso da preterição. A Rh. Al., com uma certa ingenuidade na amoralidade, dá o seguinte conselho:

Mas todos os acontecimentos demasiado difíceis de acreditar, há que omiti-los (30, 1438 b 3-4).

A detecção do procedimento é evidentemente difícil, ainda mais que é extremamente raro dispor duas versões de um processo, a da acusação e a da defesa. Há, no entanto, algumas exceções, e a mais célebre é o processo da Coroa. Somos, pois, levados a tomar para exemplo, uma vez mais, o Contra Ctesifonte.

A primeira parte da carreira política de Demóstenes examinada por Ésquines gira em torno das negociações que precederam a Paz de Filócrates entre Atenas e Felipe II da Macedônia, de 348 a 346 (data da assinatura). Uma das principais censuras que Ésquines dirige a Demóstenes é a de ter-se comprometido nessa época com o lado de Filócrates, isto é, um pacifista, enquanto que, mais tarde, Demóstenes se oporá ao partido da paz e recomendará uma política de mobilização permanente contra Felipe. A censura é uma censura de incoerência. Segundo Ésquines, Demóstenes é um político que vira a casaca. Ora, graças a Demóstenes, vimos a saber que na mesma época Ésquines mesmo passou do campo dos patriotas, ferozmente opostos a Felipe, ao campo dos "felipistas". Demais, essa virada se operou no curso da primeira embaixada, o que abre evidentemente um vasto campo para a hipótese da corrupção. O mais engraçado - e, bem entendido, esse é um ponto que Demóstenes sublinha - , é que Ésquines havia sido enviado para perto de Felipe... a fim de vigiar os seus colegas e de evitar que 
eles fizessem concessões demais ao rei (cf. Demóstenes, Embaixada, 12). Pois bem, procurar-se-ia em vão no Contra Ctesifonte uma justificação qualquer dessa reviravolta. Parece exagero, mas é preciso ter sempre em mente que esses discursos eram transmitidos ao seu público oralmente; no processo da coroa se acrescenta a distância cronológica que separa o discurso dos acontecimentos relatados (16 anos); acrescentemos que Ésquines perdeu o seu processo. Reciprocamente, Demóstenes é quase mudo na sua réplica a Ésquines sobre a sua ação no período posterior a Queronéia e em particular sobre a sua atitude em face de Alexandre.

Em todo caso, o que nos ensina o manual de retórica é que é preciso sempre estar atento ao não-dito, aos silêncios, na medida em que outras fontes nos permitam delimitar mais ou menos a verdade dos fatos.

\subsubsection{Defloração}

Passemos à defloração do argumento do adversário. Ainda se trata, aqui, de um procedimento de retórica empírica, fundado sobre a força da novidade no espírito dos ouvintes. O retor descreve um procedimento, chamado procatalepse, que consiste em ocupar antecipadamente a posição do adversário (é uma metáfora militar), isto é, antecipar-se aos seus argumentos previsíveis. Ele comenta:

Mesmo se os argumentos aos quais nos antecipamos são inteiramente fortes, sua importância não será mais a mesma para aqueles que já os terão ouvido (Rh. Al., 18, 1433 a 38-39).

A utilização da procatalepse é quase sistemática. Ela constitui mesmo uma das cinco partes do discurso na Rh. Al.: exórdio, narração, confirmação (argumentação), procatalepse, epílogo. Descobrimo-la em discursos em que há fórmulas como: talvez ele dirá que... eu ouvi dizer que ele apresentaria a seguinte defesa, etc. Citemos o Contra Ctesifonte:

Quanto a esse argumento invencível de que fala Demóstenes, voulhe responder com poucas palavras (17).

Ora, Ésquines é o acusador; por conseguinte, Demóstenes ainda não falou.

Para verificar o caráter tópico do procedimento, abrimos ao acaso o vol. II dos discursos de Lísias e deparamos com o Contra Nicômaco. Ora, lemos nele (7): "Pode 
ser, juiz, que em desespero de causa ele tente me caluniar...", e, mais adiante: "Se por acaso ele afirma que...".

\subsubsection{Exploração das induções espontâneas}

Visamos aqui à exploração de proposições como "quem bebeu, beberá”, "quem tem hábitos duvidosos, forçosamente agiu mal", "quem tem o espírito de família, será leal como político", etc. Essas proposições fundamentam-se ao mesmo tempo em elementos de retórica empírica, isto é, elas se apóiam sobre a tendência do público ao prejulgamento e à generalização abusiva, mas também em elementos quase lógicos, pois um dos seus fundamentos é o éı

Esse duplo fundamento explica que se encontrem desenvolvimentos sobre essa questão ao mesmo tempo na $\mathrm{Rh}$. Al. e na Retórica de Aristóteles. Dito isso, há diferenças significativas entre o retor e o filósofo: a apresentação do autor da $R h$. Al. é voltada não para os fatos, mas para o que se passa no espírito dos ouvintes. Se procurássemos, aliás, traçar a fronteira entre a retórica pré- e pós-aristotélica, poderíamos apoiar-nos sobre esta diferença: o sofista interessa-se, antes de tudo, pela recepção da mensagem, ele especula sobre as fraquezas intelectuais e morais do público, ao passo que Aristóteles, se leva em conta esses fatores, privilegia a argumentação quase lógica, isto é, a aplicação de esquemas de raciocínio rigorosos a fatos não susceptíveis de demonstração.

Mas sejamos mais precisos. Aristóteles diz que a culpabilidade de um criminoso não é sempre demonstrável. Há que distinguir, então, graus de probabilidade de ordem

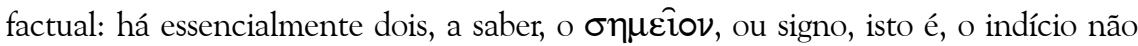
necessário. Há uma mancha de sangue na casa, é um indício de crime. Mas esse indício não tem força lógica coerciva. Alguém pode muito bem ter degolado um coelho. Em

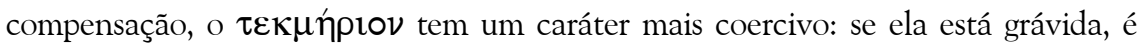
porque teve relações com um homem. Vê-se que a análise tem por finalidade colocar o problema do éı́ós em relação com a realidade dos fatos. No domínio dos meios de persuasão não-técnicos, é também a relação com os fatos que é privilegiada.

Ao contrário, na retórica sofística, o éı́ós permanece como de ordem geral e se analisa em termos de prejulgamentos. Leiamos a definição do Élkós na Rh. Al.:

O verossímil é aquilo de que, quando alguém o diz, o público tem exemplos em mente. Quero dizer, por exemplo, que se alguém afirmasse desejar que sua pátria fosse grande, seus próximos felizes, seus inimigos infelizes, e assim por diante, pois bem, < tais afirmações $>$, 
para dizê-lo numa palavra, pareceriam verossímeis. Pois cada um dos ouvintes tem consciência, sobre essas questões e as questões de mesma natureza, de experimentar pessoalmente tais desejos $(7,1428$ a 25-31).

Seguem-se não somente preceitos sobre a exploração desses prejulgamentos ("jamais causei aborrecimentos a ninguém; então, se eu empreendo esse processo, é constrangido e forçado"), mas também preceitos sobre a destruição desses procedimentos: "não é justo condenar-me por causa de meus hábitos. Se eu tenho amigos duvidosos, isso não quer dizer que eu me porto como eles".

O que se constata, pois, é que, pensado em termos de prejulgamentos, o verossímil é um meio de persuasão reversível. Todo o mundo conhece o argumento chamado córax, que consiste em dizer que uma coisa é tanto mais verossímil quanto mais inverossímil ela é e vice-versa. Se um homem robusto é acusado de haver maltratado um homem fraco, a verossimilhança o derrota; mas ele poderá dizer, todavia, que ele não é tolo ao ponto de atacar alguém menos forte que ele, sabendo que se tirará argumento da verossimilhança.

Não queremos dizer que a retórica sofística não leva em conta os fatos. Mas a utilização mesma dos fatos é sempre guiada pelo princípio de reversibilidade. No desenvolvimento sobre o exemplo $(\pi \alpha \rho \alpha ́ \delta \varepsilon \imath \gamma \mu \alpha)$, o retor insiste sobre a diferença entre

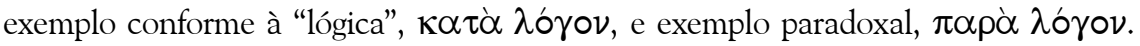
Ele afirma também que o exemplo é complementar do verossímil. Por quê? Porque, no domínio deliberativo, isto é, quando se especula sobre o futuro (mas o princípio pode aplicar-se também ao judiciário), pode-se dar que alguém tenha escolhas políticas contrárias ao Ėı́ós. Pode-se aconselhar, por exemplo - por uma razão ou por outra a declarar guerra a uma cidade mais forte. Nesse caso, o verossímil é um entrave. Os fatos, sob a forma de exemplos, serão escolhidos então entre os fatos paradoxais: citarse-ão vitórias de pequenos exércitos contra grandes - a começar por Salamina. O retor acrescenta que é preciso multiplicar esses exemplos paradoxais: jogando com o efeito de massa, poder-se-á anular completamente a fraca probabilidade da vitória.

A utilização do Ėı mesmo tempo simples e engraçado, o do Sobre o Inválido de Lísias. O querelante é um homem envelhecido, enfermo, e que recebe, nessa qualidade, uma pensão. Ele provavelmente tem a língua comprida demais e arranjou alguns inimigos. Um deles o ataca na justiça a fim de que se lhe retire a pensão. Para se defender disso, o inválido é levado a evocar a imputação de insolência que lhe valeu a inimizade de seu acusador: 
Ele sustenta também que sou insolente, brutal e muito grosseiro, como se ele só pudesse dizer a verdade empregando grandes palavras, para as quais não bastasse uma linguagem moderada. Importa-vos, creio eu, distinguir bem os homens que se podem permitir ser arrogantes, e aqueles que não o podem. A insolência não é admissível entre os pobres diabos, os miseráveis, mas entre os ricos, que têm mais que o necessário; nem entre as pessoas que têm um corpo débil, mas entre aquelas que mais se podem fiar em suas forças; nem entre os homens já avançados na idade, mas entre aqueles que ainda são jovens e que têm os sentimentos da juventude. Os ricos, com seu dinheiro, pagam para não serem incomodados; mas os pobres, a falta de dinheiro os obriga à moderação. Presume-se que as pessoas jovens têm direito à indulgência dos anciãos, ao passo que, se os anciãos cometem lá o seu erro, jovens e velhos entram em acordo para censurá-lo. É também permitido ao homem robusto insultar impunemente a quem lhe apraz; mas o fraco, esse é igualmente incapaz, quando alguém o insulta, de repelir o agressor e, se lhe dá o capricho de insultar os outros, de levar a melhor. Assim, não é seriamente, imagino, que o acusador fala de minha insolência: ele quer gracejar (16-18).

O que é notável, aqui, é que o verossímil é dado como argumento e forma o objeto de uma análise sistemática de três termos: sou pobre demais, fraco demais e velho demais para poder permitir-me a insolência, pois a insolência é a priori um defeito de ricos, de robustos e de jovens. Logo, não sou insolente. No caso mesmo, o querelante não diz uma só palavra da realidade dos fatos.

\subsection{Reviramento do código}

Passemos ao segundo modo de utilização do código retórico, na qualidade de arma voltada contra o adversário. Com efeito, um dos dados empíricos com os quais se confrontou o retor é que a competência retórica desperta a suspeita. O orador hábil é suspeito de poder, portanto de querer enganar. Em face desse fenômeno, o autor da Rh. Al. propõe duas estratégias complementares, das quais a primeira releva, antes, da sobredeterminação do código. Tornaremos a falar disso. A segunda consiste em arruinar a pertinência do discurso ressaltando o seu caráter retórico. A estratégia é descrita a propósito da procatalepse, ou antecipação, da qual já se falou. Numa deuterologia, é possível que se tenha de rebater uma antecipação. Citemos: 
Quando falamos em segundo lugar e os adversários se anteciparam àquilo que íamos dizer, é preciso rebater essas antecipações ( $\alpha \nu \tau \imath \pi \rho \circ \kappa \alpha \tau \alpha \lambda \alpha \mu \beta \alpha \dot{\alpha} \varepsilon \imath \imath v)$, refutando-as assim: "esse indivíduo, não contente de se estender diante de vós em mentiras contra mim, como ele sabia bem que eu ia confundi-lo, antecipou-se, além disso, ao meu discurso e o denegriu antecipadamente, a fim de que vós não lhe prestásseis a mesma atenção ou que eu mesmo renunciasse a vo-lo expor, porque ele o teria desacreditado antecipadamente. No entanto, creio que vós deveis ser informados de minha versão dos fatos pela minha boca, não pela sua, e que, se ele chegou a desacreditar antecipadamente em seu discurso isso mesmo que eu digo, não é um minguado indício do fato de que ele não diz nada de sensato" (18, 1433 a 40-1433 b 10).

O que é notável, aqui, é que o retor aconselha, nesse caso, a revelar o ardil retórico e o seu fundamento psicológico: a força da novidade, e a prontidão do fastio destilado pela repetição. Um belo exemplo dessa contra-antecipação se encontra no Sobre a Coroa:

Além do mais, como se ele mesmo houvesse em seu discurso usado de franqueza e de patriotismo, ele vos dizia que me vigiásseis e me observásseis de modo a evitar serdes iludidos e enganados por mim; ele me chamava homem astuto, feiticeiro, sofista, etc., como se, tomando alguém a dianteira dizendo de um outro aquilo que se aplica a si mesmo, a realidade fosse tal, e como se os ouvintes não fossem mais examinar esse mesmo que fala assim. Quanto a mim, sei que todos vós o conheceis e que pensais que esses qualificativos se aplicam muito mais a ele do que a mim (276).

Mas essa estratégia é bastante rara, e se assiste mais correntemente ao reviramento global do domínio do código retórico, apresentado como um vício que tira à fala do adversário toda a credibilidade. Ainda aí, podemos reportar-nos ao Contra Ctesifonte e justamente às passagens às quais Demóstenes acaba de responder. A competência oratória lendária de Demóstenes se torna um dos principais pontos de acusação, na qualidade de fator agravante das imputações de corrupção e de traição. O talento de Demóstenes, seu domínio da retórica permitem fazer dele um personagem perigoso por sua habilidade mesma. Ésquines começa por opor a eloqüência e o comportamento na vida real: 
Quanto ao julgamento e à eloqüência, como ele é? Hábil nas palavras, perverso na sua vida (174).

Lê-se um pouco mais adiante:

Lembrai-vos disto, quando ele diz que é um democrata: considerai não as suas palavras, mas a sua vida, e considerai não o que ele diz ser, mas o que ele é (176).

O talento oratório de Demóstenes se torna mesmo o suporte de uma verdadeira estratégia defensiva de tendência paranóica - se se ousa dizer. Ésquines (Contra Ctesifonte, 205-209) chega, com efeito, a ditar aos ouvintes a atitude que eles deverão ter quando Demóstenes lhes falar, dando a entender que todo o seu discurso não passará de uma vasta armadilha. Para se defender, os ouvintes deverão exigir que ele siga o mesmo plano que a acusação. Se ele pede a liberdade de organizar o seu discurso à sua maneira, eles deverão recusar, pois é um fingimento destinado a enganar o tribunal; eles não deverão autorizar-lhe digressão alguma; se ele procura dividir o auditório criticando os partidários de Ésquines como partidários da oligarquia, ao passo que ele seria o representante dos democratas: é preciso lhe opor a solidariedade e o esquecimento das querelas na recordação da restauração democrática de 403 e da anistia que se seguiu; se ele presta um novo falso juramento, é preciso lhe mostrar que, para que um tal ardil funcione, são necessárias duas condições: que os deuses sejam novos e os ouvintes diferentes; quando ele chorar e procurar suscitar a piedade do público, será preciso fazê-lo notar que Atenas merece muito mais a piedade do que ele. Essa passagem analisa e denuncia a estratégia retórica presumida de Demóstenes e a sua habilidade mesma como totalmente enganosas. Um pouco adiante, Ésquines foi mesmo mais longe: ele reduziu o processo de ilegalidade a uma simples confrontação entre a proposição que está em causa e o texto da lei (199). Nesse caso, nenhuma necessidade de defensor para o acusado, donde esta apóstrofe a Ctesifonte:

Demonstra que o teu projeto e as leis estão de acordo e deixa a tribuna. Que necessidade tens de fazer Demóstenes falar? Mas, é bom que saibas, quando tu esquivas uma defesa honesta e chamas para a tribuna um velhaco que se passa por mestre na arte das palavras, tu enganas os ouvintes, tu prejudicas o Estado, tu destróis a democracia (200).

Há alguma coisa de surpreendente nessa retórica que tenta arruinar radicalmente a habilidade retórica do adversário por meio dela mesma e que diz, em resumo: 
"quanto mais ele vos persuadir, menos devereis acreditar". O problema, com essa estratégia de Ésquines, é que ela é fácil de revirar. É, claro, o que Demóstenes faz na passagem a que aludíamos precedentemente.

\subsection{Negação do código}

Ao lado do reviramento do código retórico, e freqüentemente como corolário (alguém afirma ser tanto menos competente em retórica quanto é hábil o adversário), vem a negação do código. Daí as inumeráveis declarações de ingenuidade, até de ansiedade, associadas ao tema da veracidade. O raciocínio implícito é o seguinte: eu não sou bastante malicioso nem bastante competente em retórica para estar em condição de mentir; vou, pois, dizer a verdade.

É um aspecto do código - pois recusar a retórica é ainda fazer retórica - que corresponde a uma espécie de desgaste das técnicas de persuasão, que se tornaram conhecidas demais, e portanto visíveis demais. $\mathrm{O}$ autor da $\mathrm{Rh}$. Al. propõe sobre esse ponto uma dupla estratégia. Uma consiste em admitir sua competência retórica, sobredeterminando essa confissão. Voltaremos a isso. A outra consiste em sublinhar sua inferioridade. Citemos o preceito - dado a propósito do gênero deliberativo:

Há que também levar em conta as próprias deficiências ( $\varepsilon \lambda \alpha \tau \tau \omega \sigma \varepsilon \varepsilon \iota$ $\phi \varepsilon ́ p \varepsilon \imath v)$ dizendo que: "se eu me levantei para falar, não é porque eu me fie em minha habilidade ( $\delta \varepsilon \imath \nu o ́ \tau \eta \varsigma)$, mas porque penso introduzir uma proposição útil para a comunidade" (Rh. Al., 29, 1436 b 34-36).

A prática dessa negativa é muito corrente. Encontramo-la no Contra Eratóstenes de Lísias:

No que me concerne, juízes, jamais me ocupei de processo algum, nem por minha conta, nem pela dos outros, e foi preciso que as circunstâncias me obrigassem hoje a acusar esse homem. Também fui tomado muitas vezes de um profundo desânimo, temendo, falto de experiência, não poder sustentar a acusação com a devida habilidade, em nome do meu irmão e do meu (3).

Outro exemplo, a primeira frase do discurso Sobre o assassínio de Herodes de Antifonte (processo de um homem acusado, pelos pais da vítima, do assassínio de um companheiro de viagem): 
Eu gostaria, juízes, de que a habilidade da palavra e a experiência dos processos fossem iguais em mim aos males que me oprimem; mas, se experimentei estes até passar da conta, sou desprovido dos outros mais do que deveria (1).

$\mathrm{Na}$ Acusação de envenenamento contra uma madrasta, a mesma coisa:

Eu sou jovem, juízes, não tenho a experiência dos processos.

\subsection{Sobredeterminação do código}

Devemos explicar-nos um pouco a respeito disso que entendemos por “sobredeterminação do código". Empregamos a palavra sobredeterminação num sentido próximo do sentido psicanalítico. Trata-se de carregar a utilização do código com um excesso de intenções e de sentidos. Isso supõe, num primeiro momento, que essa utilização do código seja admitida pelo orador. "Sim, eu conheço a retórica e eu a utilizo". Num segundo momento, mais ou menos explícito, a utilização do código é motivada em segundo grau. É possível, cremos, distinguir três formas possíveis para esse segundo estágio do processo:

- negação da perversidade do código retórico: "Sim, eu conheço a retórica, e daí? que mal há nisso?";

- necessidade do seu emprego em face de um adversário vicioso: "Sim, eu conheço a retórica, mas o que eu faria sem ela?";

- reconhecimento da sua perversidade eventual: "Sim, eu conheço a retórica, mas você também”. Isso torna a convidar o público para um jogo: você vai ver comigo!

São aspectos particularmente difíceis de analisar e mesmo de detectar nos textos, pois implicam a instalação de uma espécie de conivência com o auditório a respeito da natureza, da função e do valor do código, conivência que a língua escrita reflete provavelmente menos bem que a língua oral.

Mas comecemos pela vertente retórica. Na Rh. Al. essa sobredeterminação aparece a propósito das imputações negativas de que é preciso se desembaraçar se se quer que o público acolha o discurso favoravelmente: 
Se alguém nos critica dizendo que pronunciamos discursos escritos antecipadamente, ou que treinamos para falar, ou então que agimos como o sinégoro em troca de retribuição, é preciso, contra tais imputações, ir ao ataque ironizando: sobre o fato de escrever os próprios discursos, diremos que a lei não pró́be a ninguém dizer um texto escrito, nem proíbe ao adversário falar sem haver redigido, pois a lei proíbe fazer isso ou aquilo, mas deixa inteira liberdade de falar como se quer. É preciso dizer também que "meu adversário considera que procedi tão mal que, na sua opinião, a acusação não estaria à altura se eu não escrevesse meu discurso de defesa e não passasse muito tempo refletindo" (...). Se os adversários sustentam que nós aprendemos a arte de falar e que fazemos exercícios, concordaremos com isso dizendo: "Nós, os oradoresaprendizes, como tu falas, não somos chicaneiros, mas tu, que não sabes falar, pões-te agora contra nós, e já no passado, em flagrante delito de delação". Surgirá, então, interesse, da parte dos cidadãos, por que também ele aprenda a retórica, pois, desse modo, não seria um delator tão ruim $(36,1444$ a $18-34)$.

Constata-se nessa passagem o emprego da palavra ironia - que introduz o segundo grau e a conivência com o público - e a habilidade do método que consiste primeiro em confessar a falta para imediatamente lhe anular a qualificação (a lei não o proíbe) ou invertê-la (é melhor ser retor e honesto que ignorante e desonesto).

O processo da coroa é a priori o contexto em que se pode descobrir esse tipo de estratégia. Lembramo-nos do motivo, recorrente em Ésquines, da habilidade oratória de Demóstenes. Este último responde, em resumo: sim, sou um hábil orador, mas o meu talento esteve a serviço do bem da pátria, ao passo que o talento de Ésquines nada fez senão prejudicar o Estado. Citemos:

Bem sei, ainda, que quanto à minha habilidade oratória...( $\delta \varepsilon \imath v o ́ \tau \eta \varsigma)$ - vá, seja essa a palavra; no entanto, vejo que na maior parte das vezes o poder do orador depende dos ouvintes; pois é segundo o acolhimento que fazeis a cada um e a simpatia que lhe testemunhais que o orador passa por inteligente. Em todo caso, se eu tenho alguma experiência nesse domínio, vereis todos que, nos processos públicos, reconheceu-se que essa habilidade sempre agiu no vosso interesse, jamais contra vós, mesmo nos meus atos privados; quanto à habilidade desse indivíduo, dá-se o contrário, não somente pelo fato de que ele fala em favor do 
inimigo, mas também porque ele fala contra quem quer que o tenha incomodado ou lhe feito obstáculo (Sobre a Coroa, 277).

Nessa passagem, a utilização do código retórico é assumida, a consciência dessa utilização é partilhada com o auditório ("reconheceu-se que essa habilidade sempre agiu no vosso interesse") e, certamente, a qualificação moral dessa prática é invertida, pelo menos no caso de Demóstenes. É possível que haja aí uma reminiscência de Górgias, segundo o qual retórica e moral são domínios perfeitamente distintos. Por conseguinte, a técnica oratória nada tem a ver com o uso, moral ou imoral, que dela se faz.

Para a utilização lúdica do procedimento, podemos reportar-nos a uma outra passagem do Sobre a Coroa. Demóstenes responde ao paralelo estabelecido por Ésquines entre ele e os bons democratas do passado, segundo o procedimento de amplificação de que falamos. Mas em vez de denunciar o procedimento, Demóstenes corrige sua aplicação e dá a Ésquines uma verdadeira lição de retórica. A passagem estabelece, então, uma conivência entre o auditório e o orador sobre a existência do código e sobre a comunidade de seu conhecimento e de seu domínio; depois o orador se põe a competir sobre esse plano com Ésquines. A dimensão irônica da passagem é atestada pelo emprego da apóstrofe desdenhosa $\widehat{\omega} \chi \rho \eta \sigma \tau \hat{\varepsilon}$ ("meu querido") cujo emprego no segundo grau é descrito na Rh. Al. (21, 1434 a 26-29). Mas citemos Demóstenes:

\begin{abstract}
Aliás, tu dizes que eu não tenho nada em comum com esses antigos democratas. E tu? Tu te pareces com eles, Ésquines? E o teu irmão? E algum outro orador dos de agora? Eu digo: ninguém. Mas, meu querido - para não dizer outra coisa - é em comparação com os vivos, com os contemporâneos, que se deve fazer o exame críticó ' $\varepsilon \xi \varepsilon \tau \dot{\varepsilon} \zeta \varepsilon \iota^{2} \nu$ dos vivos; é assim que se faz também em todos os outros casos, para os poetas, os coros, os atletas (318).
\end{abstract}

A alusão ao código retórico é clara com o verbo ' $\varepsilon \xi \varepsilon \tau \dot{\alpha} \zeta \varepsilon \imath v$, que corresponde a um tipo de discurso, o discurso de exame, descrito na Rh. Al. nos capítulos 5 e 37 . O preceito retórico está no imperativo, e seu caráter normativo é sublinhado pela extensão a outras categorias além dos oradores (poetas, coros, atletas).

\title{
Conclusão
}

Pensamos que esses poucos exemplos sejam suficientes para mostrar o quanto a utilização da $\mathrm{Rh}$. Al. poderia alimentar e enriquecer a leitura dos oradores, mediante 
uma exploração mais completa das aproximações possíveis. Terminaremos desejando a publicação de artigos em que seria explorada, discurso após discurso, autor após autor, essa hiper/intertextualidade, abordada de um duplo ponto de vista, poético (no sentido etimológico do termo, como estudo do processo criador) e pragmático - com a investigação a levar em conta, o mais precisamente possível, os dados concretos da comunicação retórica e as suas repercussões sobre o texto produzido.

Tradução integral

MARCELO VIEIRA FERNANDES** Faculdade de Filosofia, Letras e Ciências Humanas da Universidade de São Paulo

\section{Notas}

* Professor Doutor de Língua e Literatura Grega da Université de Paris XII - Val de Marne e Diretor do Departamento de Letras (Modernas e Clássicas).

** Mestrando em Latim do Programa de Pós-Graduação em Letras Clássicas da FFLCHUSP.

1 Este artigo é a versão desenvolvida de uma comunicação apresentada no XI ${ }^{\circ}$ congresso da International Society for the History of Rhetoric (Saskatoon, julho de 1997).

2 Nossa edição, revista por Michel Patillon, está atualmente (maio de 2001) no prelo.

3 Anaximenis Ars Rhetorica, Turici e Vitoduri, 1844 (Hildesheim 1981).

4 Uma exegese é necessária porque, contrariamente à Retórica de Aristóteles e à maior parte dos tratados posteriores, a $R h$. Al. forja seus próprios exemplos. Um único preceito é ilustrado com uma citação de autor, a antiprocatalepse (cap. 18, 1433 b 12ss), através de alguns versos do Filoctetes de Eurípides (fr. 16 Müller).

5 P. Moraux, "Thucydide et la rhétorique", Les Études Classiques, 22, 1954, p. 3-23; F. Romero Cruz, "Tucídides VI 16 y la retórica a Alejandro", Stephanion (Homenaje a María C. Giner), Salamanca, 1988, p. 149-153.

6 Paris (Collection des Universités de France), 1974.

7 Não se deve menosprezar nessa dialética o papel desempenhado pelo público ateniense (cf. infra, p. 115). Este último ouvia a cada ano um grande número de discursos, era exigente e se cansava rápido, donde um enriquecimento e uma renovação rápida das técnicas. Para uma vista de conjunto sobre esses progressos, cf. S. Usher, Greek Oratory. Tradition and Originality, Oxford, 1999, p. 21-26. Sobre a sutileza (julgada excessiva) do público ateniense, cf. - entre outros - Tucídides, III, 43, 3.

8 Ver por último a edição de H. Rackham, Rhetorica ad Alexandrum, em Aristóteles XVI, LCL, London, 1937 (1983). Muito amplamente divulgada também é a reedição da 
tradução de E. S. Forster (De Rhetorica ad Alexandrum, in W. D. Ross, ed., The Works of Aristotle transl. into English, vol. 11, Oxford, 1924) em J. Barnes, The Complete Works of Aristotle. The revised Oxford Translation, t. II (Bollingen series LXXI.2), Princeton University Press, 1984, p. 2270-2315.

9 Cf. P. Gohlke, Rhetorik an Alexander (Aristoteles, Die Lehrschriften 3, 3), Paderborn, 1959.

10 J. Sánches Sanz, Retórica a Alejandro, Salamanca, 1989.

11 Citemos, entre muitos outros títulos: J. de Romilly, Les Grands Sophistes dans l'Athènes de Périclès, Paris, 1988; M. Untersteiner, Les Sophistes, trad. française, 2 vol., Paris, 1993; B. Cassin, L'Effet sophistique, Paris, 1995.

12 Ver sobre esse ponto P. Chiron, "La tradition manuscrite de la Rhétorique à Alexandre: prolégomènes à une nouvelle édition critique”, Revue d'Histoire des Textes, 30 (no prelo).

13 F. Blab, Die attische Beredsamkeit, t. II, Leipzig, 18922, p. 391.

14 Para um estudo mais preciso desse ponto delicado - os defensores da crítica genética não chegam todos aos mesmos resultados -, cf. P. Chiron, "Aristote lecteur de la Rhétorique à Alexandre?”, em J.-F. Balaudé (ed.), Aristote lecteur, a publicar.

$15 \mathrm{Na}$ sua tese: Fórmulas Retóricas de la Oratoria Judicial Ática, Salamanca, 1986. Ver também, do mesmo autor: "Orígenes de la súplica retórica a los jueces", Anuario de Estudios Filológicos, 9, 1986, p. 89-100. Deve-se precisar que F. Cortés Gabaudán procede mais pela confrontação dos discursos com os discursos. O código retórico, representado pela Rh. Al. mas também pela Retórica de Aristóteles, a Retórica a Herênio, os Tratados de Cícero, etc., não ocupa mais do que um lugar relativamente menor.

16 Ver sobre esse ponto P. Chiron, "Sur une série de pisteis dans la Rhétorique à Alexandre (Rh. Al., cap. 7-14)”, Rhetorica, 16, 1998, p. 349-391.

17 As divisões que apresentamos não se querem nem rígidas nem definitivas. São apenas proposições, sujeitas a discussão, a contestação e a revisão.

18 Pensamos neste desafio de Górgias (Platão, Fedro, 267 a 6ss) e de Isócrates (Panegírico, 8): pela palavra, rebaixar as coisas grandes e engrandecer as pequenas, dar um caráter novo ao que é antigo...

19 Cf. Rh. Al., 7, 1428 b 26-29: “<se> aquele que tu acusas é jovem, aquilo que fazem as pessoas dessa idade, dize que ele fez: em razão da semelhança, conceder-se-á crédito também às acusações apresentadas contra ele".

20 M. H. Hansen, La démocratie athénienne à l'époque de Démosthène, trad. française, Paris (Les Belles Lettres), 1993 (1ª ed. Oxford, 1991), p. 176.

21 M. Fuhrmann (ed.), Anaximenis Ars Rhetorica, Leipzig, 1966 (2a ed., Munich e Leipzig, 2000), p. 21.

22 Eschine, Discours II, ed. V. Martin et G. de Budé, Paris, 1952.

23 Aeschines, Orationes, ed. M. R. Dilts, Leipzig, 1997.

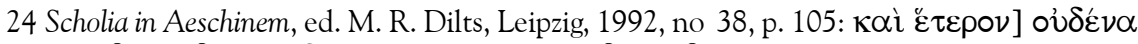

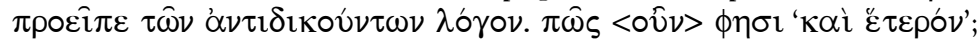

25 Cf. Lysias, Discours II, éd. L. Gernet et M. Bizos, Paris (CUF), p. 147, n.3. 
26 Démétrios, Du Style, éd. P. Chiron, Paris (CUF), 1993.

27 Assim, em Isócrates: Sobre a atrelagem, 16; Eginético, 18; Plataico, 27; no corpus transmitido sob o nome de Lísias: Epitáfio, 27; Contra Simão, 5; Contra Agorato, 65; Peroração sobre uma confiscação (disc. XVIII), § 3; Contra Nicômaco, 2; Contra Diogitão, 26. Ver também,

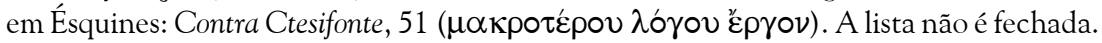

28 Essa fórmula é tomada de empréstimo a Chaïm Perelmann, que freqüentemente a emprega, por exemplo em L'empire rhétorique, Paris, 1988, p. 69ss.

29 Cf. Aristóteles, Retórica, I, 1357 b 3ss.

30 A passagem ilustra tão bem o preceito que parece comportar uma dimensão metadiscursiva, em todo caso um segundo grau e humor. Há algumas que podem fazer pensar que o Sobre o Inválido é um “jogo de espírito”, um paignion, cf. S. Usher, op. cit., p. 106110.

31 Ela é freqüentemente associada ao tema do cidadão tranqüilo, nem ativista, nem sicofanta, tema recorrente, cf. L. B. Carter, The Quiet Athenian, Oxford, 1986.

CHIRON, Pierre. La Rhétorique à Alexandre et les orateurs attiques.

RÉSUMÉ: Le premier avatar de la rhétorique n'est-il pas de passer de l'état de précepts à l'état de discours? Malheureusement, celui ou celle qui cherche à enrichir la lecture des orateurs grecs antiques par une comparaison avec le code de prescriptions élaboré par les rhéteurs se heurte à une difficulté: notre documentation technique s'enrichit, avec la Rhétorique d'Aristote, au moment même où la pratique oratoire décline. On hésite donc, avec raison, à établir des corrélations entre les deux, et cela d'autant plus qu'Aristote peut être crédité d'une véritable refondation de la rhétorique: avec hi, même si une bonne part du matériau technique se maintient, les principes, la méthode et la terminologie évoluent considérablement. Il exist pourtant un traité qui - tout en étant très proche chronologiquement de la Rhétorique d'Aristote - fournit sans doute, étant donné sa date (ca 340?) et son orientation sophistique, un large aperçu sur l'enseignement des rhéteurs pré-aristotéliciens, c'est la Rhétorique à Alexandre, couramment attribuée, depuis Pier Vettori, à Anaximène de Lampsaque. Nous nous proposons ici de constituer les grandes lignes d'une méthode destinée à exploiter systématiquement cette ancienne version du code rhétorique pour l'exégèse des orateurs attiques, et d'en donner quelques applications.

MOTS-CLEFS: rhétorique grecque pré-aristotélicienne; orateurs attiques; Rhétorique à Alexandre. 